\title{
Green Marketing and Its Incidence in the Decisions of Purchase of Peruvian University Students
}

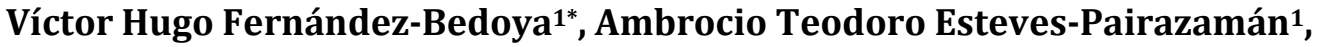 \\ Rosario Violeta Grijalva-Salazar' ${ }^{1}$, Walter Gregorio Ibarra-Fretell'1, \\ Susana Edita Paredes-Díaz1, Josefina Amanda Suyo-Vega1, \\ Mónica Elisa Meneses-La-Riva1, Jorge Luís Aníbal Baldárrago-Baldárrago1, \\ Víctor Raúl Reátegui-Paredes ${ }^{2}$, Robert Willie Chávez-Mayta ${ }^{3}$ \\ ${ }^{1}$ Universidad César Vallejo, Trujillo, Perú \\ ${ }^{2}$ Universidad Nacional de la Amazonía Peruana, Iquitos, Perú \\ ${ }^{3}$ Opción Perú, Lima, Perú \\ Email: *victorhugofernandezbedoya@gmail.com
}

How to cite this paper: Fernández-Bedoya, V.H., Esteves-Pairazamán, A.T., Grijalva-Salazar, R.V., Ibarra-Fretell, W.G., Paredes-Díaz, S.E., Suyo-Vega, J.A., Meneses-La-Riva, M.E., Baldárrago-Baldárrago, J.L.A., Reátegui-Paredes, V.R. and ChávezMayta, R.W. (2020) Green Marketing and Its Incidence in the Decisions of Purchase of Peruvian University Students. Modern Economy, 11, 1-9.

https://doi.org/10.4236/me.2020.111001

Received: October 29, 2019

Accepted: January 5, 2020

Published: January 8, 2020

Copyright $\odot 2020$ by author(s) and Scientific Research Publishing Inc. This work is licensed under the Creative Commons Attribution International License (CC BY 4.0)

http://creativecommons.org/licenses/by/4.0/

\begin{abstract}
There is a current problem that companies have when they do not know if their position declared through green marketing is effective or not, since there are no studies that prove its real impact on the young population, specifically on university students in Lima, so the research question is: how green marketing affects the purchasing decisions of university students in Lima, 2019? Before that, it is proposed as a hypothesis: green marketing positively affects the purchasing decisions of university students in Lima, 2019. The study is of an applied and explanatory type, with a non-experimental cross-sectional design. We obtained data from a sample of 622 university students from $\mathrm{Li}-$ ma, Peru, which when treated through the Pearson Chi-Square test allows us to validate the hypotheses raised.
\end{abstract}

\section{Keywords}

Green Marketing, Purchasing Decisions, Consumer, University Students, Lima

\section{Introduction}

We live in a time of constant changes, new tools and techniques accelerate the development of the industry day after day, the technological advances are more and more frequent and with it not only the human being, but also his environ- 
ment undergoes changes. It is inevitable to come to the conclusion that the planet is degraded day after day, and that it will eventually become uninhabitable.

Many initiatives related to the care of the environment can be easily identified, whether at the local, regional, national or international level; a large part of them are aimed at raising people's awareness of environmental conservation, forming ecological awareness.

When talking about environmental pollution, the first thing that happens in our minds is the damage caused by industries, which exist precisely because of the demand that their products have for consumers, which motivates them to continue with their practices.

The environmental education has contributed to generate conscience in the population, who little by little have taken actions with respect to the protection of the environment, as for example that of preferring to acquire products that were elaborated and commercialized generating the minimum impact in the environment.

Some companies, on the other hand, aware of their environment and of this market niche, have sought to adopt environmentally friendly policies, which are communicated to this target market (green marketing).

Green marketing began to be called in the 1980s to the commercialization actions of eco-friendly products, which through diverse modifications to the offered product, internal productive process, packaging, packaging and distribution, demonstrate through responsibility, conscience and ecological sensibility their commitment with the environment, waiting for the preference of the consumer [1].

The green movement appeared precisely as a way of reacting to the negative impact that human activities have on the environment [2] [3] [4].

Today, green marketing went from being a simple activity applied by some companies to be a megatrend, which was born from the sensitivity that human beings have to their environment and the ways in which governments, companies and people are involved simultaneously.

Green marketing generates and facilitates any exchange of products while meeting human needs through care and environmental protection [5].

The vision of green marketing is not to provide products to carefree insatiable consumers, but rather to meet the needs of environmentally conscious people concerned about current world conditions.

Green marketing has two main objectives [6]:

1) To offer products according to the customer's needs, in terms of quality, functionality, quality, performance and price while being environmentally friendly.

2) To project a perception of high quality in front of the competition, communicating their environmental sensitivity with respect to the attributes of the product, which gives them a competitive advantage.

Faced with this, green marketing encourages consumers to purchase products made and marketed by companies committed to the environment and therefore 
socially responsible [7] [8] [9] [10].

If we compare the proposals framed in the application of green marketing in our country, we can notice that not all companies promote it, therefore, Peru could be considered as a relatively incipient market even, however, the increase in environmental awareness in some people has led to demand for environmentally friendly products, even the trend indicates that every day there are more followers of this kind of goods and services.

Today in Peru, business consortiums are beginning to be targeted not only by institutions and organizations related to environmental care, but are also being monitored by their own consumers, who every day demand "green" goods and services, produced and distributed in environmentally friendly circumstances.

As for the decision making during the purchase, diverse authors emphasize that it is related the preference and selection of some brand, the quantity to buy and the frequency of carrying out this action, diverse authors associate it to internal factors of each person, that influence in their habits of purchase [11] [12]. These factors could be related to their culture and values [13] [14], their demographic characteristics [13], perceptual patterns [15] [16], among others.

Purchasing decisions motivated by cultural aspects and personal values are made on the basis of accumulated feelings and people's prioritization of the various products, their possessions and their own environment [17] [18]. Values can play a predominant role in consumers' purchasing decisions, since people tend to choose from the diversity of products offered those that are compatible with their personal values, and therefore consistent with their culture [19].

As background to this study, we can mention a previous one in which the authors who detailed in a scientific article the strategies related to green marketing used by companies worldwide, in relation to product, price, place and promotion, showing what was the result for the companies Coop Sweden, Naturaline, Ricoh, Ericcson and Carpak [20]. In turn, other authors, also details in a scientific article how the growing concern for the environment has motivated companies to develop policies that result in a reduction of their environmental impact [21]. On the other hand, it has also been detailed in another previous study, in an exploratory manner, the preferences of green consumers in a Colombian town (Aburrá Valley) [22]. In the Peruvian context, we can identify as antecedent a study carried out in the department of Puno [23], which details how the conscience of ecological type affects in the consumption of some of the products of the region Puno.

It is considered a problematic reality the fact that although companies usually demonstrate their environmentalist positions through green marketing, there are no studies that prove its real effect on the young population, specifically university students in Lima, therefore, do not know if these practices really affect the purchase decisions of this market. In view of this, the following research problem was raised:

How does green marketing influence the purchasing decisions of university students in Lima, 2019? 
In addition, it was pertinent to formulate the following specific problems:

1) In what way does green marketing influence the decisions related to the brand to be bought by university students in Lima, 2019?

2) In what way does green marketing influence the decisions related to the quantity to be bought by university students in Lima, 2019?

3) In what way does green marketing influence decisions related to the frequency of purchase by university students in Lima, 2019?

In order to do so, the following general hypothesis was put forward:

$\mathrm{H}_{1}$ : Green marketing has a positive impact on the purchasing decisions of university students in Lima, 2019.

In addition, it was pertinent to formulate the following specific hypotheses:

$\mathrm{H}_{2}$ : Green marketing influences the decisions related to the brand to be bought by university students in Lima, 2019.

$\mathrm{H}_{3}$ : Green marketing affects decisions related to the amount to be purchased by university students in Lima, 2019.

$\mathrm{H}_{4}$ : Green marketing affects decisions related to the frequency of purchase by university students in Lima, 2019.

As for the objectives of this research, it is convenient to specify that they were considered general and specific. The general objective was:

To determine how green marketing affects the purchasing decisions of university students in Lima, 2019.

The specific objectives were:

1) Determine how green marketing affects the decisions related to the brand to be purchased by university students in Lima, 2019.

2) Determine how green marketing affects decisions related to the amount to be purchased by university students in Lima, 2019 .

3) Determine how green marketing affects decisions related to the frequency of purchase by university students in Lima, 2019.

As for the justification of the research, it proved to be justifiable in a theoretical, practical and methodological manner. Its theoretical justification is based on the fact that its purpose was to contribute to the existing knowledge related to green marketing, of which there is very little information on the incidence of its application in Latin American countries; it is expected that the fruits of this study may later be concretized in a proposal, which may then be incorporated as knowledge to the administrative sciences if the hypothesis is verified. It has practical justification because the development of the investigation helped to solve a problematic reality and through the findings strategies will be proposed that when applied will contribute to solve similar problems in other environments. Finally, a methodological justification is presented because the validated and applied instruments can be used by other researchers to continue with the development of scientific knowledge.

An important point to highlight of the project is that, because the impact of green marketing is analyzed, it is aligned with the following sustainable devel- 
opment objectives proposed by the UN:

1) Promote sustained, inclusive and sustainable economic growth, full and productive employment and decent work for all.

2) Build resilient infrastructure, promote inclusive and sustainable industrialization and foster innovation.

3) Ensuring sustainable consumption and production patterns.

4) Strengthen means of implementation and revitalize the global partnership for sustainable development.

\section{Method}

\subsection{Type of Study and Research Design}

The characteristic of research is that it is of an applied type. This type of research is based on pre-established theories [24], in this case related to green marketing, to identify all aspects related to the variables being studied, mainly those related to the impact on the purchasing decisions of university students. In addition, this research is explanatory in nature, since at the end of it will allow us to know the impact of green marketing in the purchasing decisions of university students in Lima in 2019. The research is explanatory, these types of research are oriented to the discovery of several essential laws that can account for-or explain, why there are such or such characteristics and why certain properties could be associated with each other, that is to say, it will guide us to know the incident factors and the relationship that exists between the variables [25]. In terms of design, this is of a non-experimental type, since researchers will observe what occurs naturally, without any intervention whatsoever [26]; it is also necessary to specify that it is transversal, because diverse data are collected at a single moment, at a single moment and their central purpose is to describe the variables for the subsequent analysis of their behavior at a given moment [27].

\subsection{Population, Sample and Sampling}

The population is the set of all cases that agree with certain specifications [28], before it is convenient to indicate that the population of this study was all university students in Lima, enrolled in 2019. The researcher did not have updated statistical information of people who meet these characteristics, and estimates that were about 100,000 individuals, so the researcher used non-probability sampling which is not based on mere probability, but depends on the decision-making process of a member of the research or rather a group of researchers [28], being simple random. As for the sample, it was made up of 622 individuals who met the characteristics of the study population.

Because non-probability sampling was used, the subjects to whom the instrument was applied were selected given the convenient accessibility and proximity of the subjects to the survey staff. However, samples were collected from the north, south, east, west and center of Lima so that the results obtained could be generalized. 


\subsection{Data Collection Techniques and Instruments}

The technique to apply was survey and the instrument was the questionnaire. This questionnaire was related to specific aspects of the research containing questions related to green marketing and purchasing decisions. The answer alternatives will be distributed on a Likert scale, with 5 levels.

The instrument was subjected to expert judgement in order to evaluate its validity, which was positive.

As for reliability, Guttman Split-Half Coefficient was applied (see Table 1), which offers a general reliability coefficient, and two specific ones (one for each half). Testing Guttman Split-Half Coefficient results in 0.832, which is highly reliable evidence.

The researchers worked together with two (02) people hired for data collection, who collected information from outside various universities located in $\mathrm{Li}$ ma.

\section{Results}

Pearson Chi-Square test was used in order to validate the hypotheses put forward above, the program used for data processing was SPSS 26.

As for $\mathrm{H}_{1}$ : Green marketing has a positive impact on the purchasing decisions of university students in Lima, 2019; the results are displayed in Table 2.

The value of the test statistic is 381.157 . The degree of freedom is 120 ; since the p-value (0.004) is less than our chosen significance level $\alpha=0.05$, we can conclude that there is an association between green marketing and purchasing decisions of university students.

As for $\mathrm{H}_{2}$ : Green marketing influences the decisions related to the brand to be bought by university students in Lima, 2019; the results are displayed in Table 3.

The value of the test statistic is 273.107 . The degree of freedom is 90 ; since the p-value (0.001) is less than our chosen significance level $\alpha=0.05$, we can conclude that there is an association between green marketing and the decisions related to the brand to be bought by university students.

As for $\mathrm{H}_{3}$ : Green marketing affects decisions related to the amount to be purchased by university students in Lima, 2019; the results are displayed in Table 4.

The value of the test statistic is 213.107. The degree of freedom is 90; since the $\mathrm{p}$-value (0.004) is less than our chosen significance level $\alpha=0.05$, we can conclude that there is an association between green marketing and decision related to the amount to be purchased by university students.

As for $\mathrm{H}_{4}$ : Green marketing affects decisions related to the frequency of purchase by university students in Lima, 2019; the results are displayed in Table 5 .

The value of the test statistic is 203.107 . The degree of freedom is 120 ; since the p-value (0.020) is less than our chosen significance level $\alpha=0.05$, we can conclude that there is an association between green marketing and decisions related to the frequency of purchase by university students. 
Table 1. Guttman split-half coefficient.

\begin{tabular}{|c|c|c|c|}
\hline \multirow{5}{*}{ Cronbach's Alpha } & \multirow{2}{*}{ Part 1} & Value & 0.822 \\
\hline & & $\mathrm{N}$ of items & $08^{\mathrm{a}}$ \\
\hline & \multirow{2}{*}{ Part 2} & Value & 0.831 \\
\hline & & $\mathrm{N}$ of items & $07^{\mathrm{b}}$ \\
\hline & \multicolumn{2}{|c|}{ Total $\mathrm{N}$ of items } & 15 \\
\hline \multicolumn{3}{|c|}{ Correlation Between Forms } & 0.819 \\
\hline Spearman-Brown & \multicolumn{2}{|c|}{ Longitud igual } & 0.832 \\
\hline Coefficient & \multicolumn{2}{|c|}{ Longitud desigual } & 0.833 \\
\hline \multicolumn{3}{|c|}{ Guttman Split-Half Coefficient } & 0.842 \\
\hline
\end{tabular}

Table 2. Pearson Chi-Square test for $\mathrm{H}_{1}$ : Green marketing has a positive impact on the purchasing decisions of university students in Lima, 2019.

\begin{tabular}{cccc}
\hline & Value & df & Asymp. Sig (2-sided) \\
\hline Pearson Chi-Square & 381.157 & 120 & 0.004 \\
Likelihood Ratio & 339.160 & 120 & 0.060 \\
Linear-by-Linear & 75.545 & 1 & 0.000 \\
N of Valid Cases & 622 & & \\
\hline
\end{tabular}

Table 3. Pearson Chi-Square test for $\mathrm{H}_{2}$ : Green marketing influences the decisions related to the brand to be bought by university students in Lima, 2019.

\begin{tabular}{cccc}
\hline & Value & d & Asymp. Sig (2-sided) \\
\hline Pearson Chi-Square & 273.107 & 90 & 0.001 \\
Likelihood Ratio & 337.460 & 90 & 0.015 \\
Linear-by-Linear & 185.344 & 1 & 0.017 \\
N of Valid Cases & 622 & & \\
\hline
\end{tabular}

Table 4. Pearson Chi-Square test for $\mathrm{H}_{3}$ : Green marketing affects decisions related to the amount to be purchased by university students in Lima, 2019.

\begin{tabular}{cccc}
\hline & Value & d & Asymp. Sig (2-sided) \\
\hline Pearson Chi-Square & 213.107 & 90 & 0.004 \\
Likelihood Ratio & 217.460 & 90 & 0.035 \\
Linear-by-Linear & 36.344 & 1 & 0.002 \\
N of Valid Cases & 622 & & \\
\hline
\end{tabular}

Table 5. Pearson Chi-Square test for $\mathrm{H}_{4}$ : Green marketing affects decisions related to the frequency of purchase by university students in Lima, 2019.

\begin{tabular}{cccc}
\hline & Value & $\mathrm{d}$ & Asymp. Sig (2-sided) \\
\hline Pearson Chi-Square & 203.107 & 120 & 0.020 \\
Likelihood Ratio & 127.460 & 90 & 0.005 \\
Linear-by-Linear & 6.344 & 1 & 0.002 \\
N of Valid Cases & 622 & & \\
\hline
\end{tabular}




\section{Conclusions}

Through the statistical analysis of the data collected from 622 people, the hypotheses raised by the authors were validated.

It could be said that green marketing has a positive impact on the purchase decisions of university students in Lima, year 2019, in its "brand", "amount" and "frequency" dimensions. Given these results, companies are suggested to develop marketing plans that consign the application of strategies that focus on environmentally friendly objectives.

\section{Conflicts of Interest}

The authors declare no conflicts of interest regarding the publication of this paper.

\section{References}

[1] Samper, J. and Echevarri, L. (2008) Acciones y prácticas de mercadeo verde en empresas colombianas (Casos de estudio). Revista de economía y \& administración, 5, 137-158.

[2] Dima, J.C. and Vladutescu, S. (2012) The Environment of Organizational Entities and Its Influence on Decisional Communication. International Journal of Management Sciences and Business Research, 1, 1-11.

[3] Macris, M. (2013) Labor International Circulation within the Present Day Context of Globalized Economy. International Journal of Management Sciences and Business Research, 2, 33-48.

[4] Vladutescu, S. (2012) The Emphasis of Negative Journalism in the Economic Communication, one of the Consequences of the Global Economic Crisis. Romanian Statistical Review Supplement, International Symposium, 60, 121-126.

[5] Polonsky, M. and Mintu-Wimsatt, A. (1996) Environmental Marketing: Strategies, Practice, Theory, and Research. The Haworth Press Inc., New York.

[6] Ottman, J. (1998) Green Marketing Opportunity for Innovation. 2nd Edition, Ottman Consulting Inc., New York.

[7] Alonso, J. and Grande, E. (2013) Comportamientos del consumidor. 7th Edition, ESIC, Madrid.

[8] Bianchi, E., Ferreyra, S. and De Gesualdo, G. (2013) Consumo responsable: diagnóstico y análisis comparativo en la Argentina y Uruguay. Estudios contables y de administración, 4, 43-79.

[9] Mohr, L. and Webb, D. (2005) The Effects of Corporate Social Responsibility and Price on Consumer Responses. The Journal of Consumer Affairs, 39, 121-147. https://doi.org/10.1111/j.1745-6606.2005.00006.x

[10] Recio, A. (2006) Consumo responsable: Una reflexión crítica. Mientras Tanto, 99, 41-47.

[11] Martínez, J. (2016) Factores externos determinantes de las decisiones de inversión a largo plazo en el sector farmacéutico. Telos, 18, 415-430.

[12] Melchor, M., Rodríguez, J. and Díaz, M. (2016) Comportamiento de compra y consumo de productos dietéticos en los jóvenes universitarios. Pensamiento \& Gestión, 41, 174-193.

[13] Araújo-Vila, N. and Fraiz-Brea, J. (2011) Comportamiento y perfil de los consumi- 
dores de series de ficción y otros productos audiovisuales en el siglo XXI. Vivat Academia, 117, 47-62. https://doi.org/10.15178/va.2011.117.47-62

[14] Márquez, A. (2005) Una mirada integral a la decisión de precios de la organización. Visión Gerencial, 1, 42-52.

[15] Manrique, L. (2014) Comportamiento de compra organizacional, una exploración del estado actual. Revista Virtual Universidad Católica del Norte, 43, 113-130.

[16] Sanabria, E. and Parra, C. (2013) Caracterización del comprador sogamoseño en súper e hipermercados. Estudios Gerenciales, 29, 49-57. https://doi.org/10.1016/S0123-5923(13)70019-6

[17] Schiffman, L. and Kanuk, I. (2015) Comportamiento del consumidor. 11th Edition, Pearson Educación de México, México City.

[18] Marandi, E., Little, E. and Sekhon, Y. (2006) The Impact of Personal Values on Perception of Service Provider Empathy and Customer Loyalty. The Business Review, 5, 339-343.

[19] Manyiwa, S. and Crawford, I. (2002) Determining Linkages between Consumer Choices in a Social Context and the Consumers' Values: A Means-End Approach. Journal of Consumer Decision, 2, 54-71. https://doi.org/10.1002/cb.89

[20] Castellano, S., Urdaneta, G. and Joheni, A. (2015) Estrategias de mercadeo verde utilizadas por empresas a nivel mundial. Telos, 17, 476-494.

[21] Salas, H. (2018) Marketing ecológico: La creciente preocupación empresarial por la protección del medio ambiente. Fides et Ratio, 15, 151-169.

[22] Escobar-Moreno, N., Gil, A. and Restrepo, A. (2015) Caracterización preliminar del consumidor verde antioqueño: El caso de los consumidores del Valle de Aburrá. Revista Escuela De Administración De Negocios, 78, 92-107. https://doi.org/10.21158/01208160.n78.2015.1192

[23] Apaza, J. (2014) La conciencia ecológica en el consumo de productos en la ciudad de Puno-Perú.Comuni@cción, 5, 5-12.

[24] Abanto, W. (2014) Diseño y desarrollo del proyecto de investigación: Guía del aprendizaje. Universidad César Vallejo, Trujillo.

[25] Díaz-Narváez, V. and Calzadilla, A. (2016) Artículos científicos, tipos de investigación y productividad científica en las Ciencias de la Salud. Revista Ciencias de la Salud, 14, 115-121. https://doi.org/10.12804/revsalud14.01.2016.10

[26] Sousa, V., Driessnack, M. and Costa, I. (2007) Revisión de diseños de investigación resaltantes para enfermería. Parte 1: Diseños de investigación cuantitativa. Revista Latino-Americana de Enfermagem, 15, 1-6.

[27] Müggenburg, V. and Pérez, I. (2007) Tipos de estudio en el enfoque de investigación cuantitativa. Enfermería Universitaria, 4, 35-38.

[28] Hernández, R., Fernández, C. and Baptista, M. (2014) Metodología de la investigación. 6th Edition, McGraw Hill, México City. 